\title{
AKTIVITAS ANTI DIABETES MELLITUS TANAMAN DURIAN (Durio zibethinus Murr.) TERHADAP KADAR GLUKOSA DARAH PUASA MENCIT YANG DIINDUKSI ALOKSAN
}

\author{
Muh. Nur Amir, Yuyun Sulitiani, Indriani, Inda Pratiwi', Elly Wahyudin, Marianti A. Manggau, \\ Sumarheni dan Ismail \\ Fakultas Farmasi, Universitas Hasanuddin, Makassar, Indonesia
}

Kata Kunci : Durian, Diabetes Mellitus, Mencit, aloksan

\section{Masuk 27-12-2019 \\ Revisi 24-01-2020 \\ Diterima $15-02-2020$}

Korespondensi

Muh. Nur Amir

nurephar@gmail.com

\section{Copyright}

(C) 2020 Majalah Farmasi Farmakologi Fakultas

Farmasi · Makassar

Diterbitkan tanggal 16-02-2020

DO

10.20956/mff.v23i3.9396

Dapat Diakses Daring

Pada:

http://journal.unhas.ac.id /index.php/mff

\begin{abstract}
ABSTRAK
Durian (Durio zibethinus Murr.) telah lama digunakan sebagai salah satu pengobatan tradisional untuk mengobati berbagai macam penyakit, termasuk untuk penderita diabetes mellitus. Penelitian ini bertujuan untuk menentukan aktivitas ekstrak etanol durian dalam menurunkan kadar glukosa darah pada mencit yang diinduksi aloksan dosis $125 \mathrm{mg} / \mathrm{kgBB}$ dan diberi beban glukosa 20\%. Sebanyak 36 ekor mencit dibagi menjadi 6 kelompok perlakuan. Kelompok I sebagai kontrol sehat, kelompok II diinduksi dengan aloksan dan diberikan NaCMC 1\% (kontrol negatif), kelompok III diinduksi dengan aloksan dan diberikan Acarbose $®$ (kontrol positif), kelompok IV diinduksi dengan aloksan dan diberikan ekstrak etanol akar durian (EDR), ekstrak klika (ESB) dan ekstrak daun (EDL) dosis $125 \mathrm{mg} / \mathrm{kgBB}$, kelompok $\mathrm{V}$ diinduksi dengan aloksan dan diberikan ekstrak etanol akar durian (EDR), ekstrak klika (ESB) dan ekstrak daun (EDL) dosis $250 \mathrm{mg} / \mathrm{kgBB}$, kelompok VI diinduksi dengan aloksan dan diberikan ekstrak etanol akar durian (EDR), ekstrak klika (ESB) dan ekstrak daun (EDL) dosis $500 \mathrm{mg} / \mathrm{kgBB}$. Pengukuran kadar glukosa darah dilakukan sebelum induksi alloxan ( $\mathrm{t}-0), 3 \times 24$ jam setelah induksi ( $\mathrm{t}$ 3), dan setiap 30 menit setelah pemberian perlakuan ekstrak dan larutan glukosa hingga menit ke-180 (t30, t60, t90, t120, t150 dan t180), yang dilakukan pengukuran menggunakan alat glukometer (Nesco®). Persen penurunan kadar glukosa darah yang paling tinggi ditunjukkan setelah menit ke-180 pada kelompok EDR dengan dosis $125 \mathrm{mg} / \mathrm{kgBB}$, ESB dosis $250 \mathrm{mg} / \mathrm{kgBB}$ dan EDL dosis $500 \mathrm{mg} /$ kgBB yaitu sebesar 50,60\%, 105,62\%, dan 62,97\%.
\end{abstract}

\section{PENDAHULUAN}

Diabetes mellitus merupakan salah satu gangguan metabolik yang ditandai dengan hiperglikemia akibat berkurangnya sekresi insulin atau penurunan efektifitas insulin atau keduanya. (1).

Menurut data dari American Diabetes Association pada tahun 2017 diperkirakan ada 415 juta orang dewasa berusia 20-79 tahun menderita diabetes mellitus di seluruh dunia, termasuk 193 juta yang tidak terdiagnosis dan sebanyak 318 juta jiwa lainnya diperkirakan mengalami gangguan toleransi glukosa (2). Peningkatan prevalensi diabetes mellitus lebih tinggi sehingga menjadi sangat penting untuk segera diobati (3).

Salah satu cara untuk mengurangi penyakit diabetes adalah dengan mengkonsumsi obat berbahan tradisional karena telah digunakan secara empiris oleh masyarakat tradisional Indonesia (4). Durian merupakan salah satu tanaman yang habibatnya cukup besar di Inonesia dan memiliki potensi yang cukup besar sebagai salah satu obat tradisional.

Durian adalah salah satu tanaman yang paling banyak tumbuh di kawasan Asia Tenggara, terutama di Indonesia yang memiliki iklim tropis. Tanaman durian memiliki banyak kandungan dan manfaat di setiap bagiannya. Kulit buah durian mengandung minyak atsiri, flavonoid, saponin, unsur selulosa, lignin, serta kandungan pati. Daunnya mengandung saponin, flavonoid dan polifenol, sementara akarnya mengandung tannin. Durian juga banyak mengandung vitamin B1, vitamin B2, dan vitamin C, serta kalium, kalsium dan fosfor. Daun dan akar durian digunakan sebagai antipiretik, daun durian dapat digunakan untuk mengobati demam, buah durian dapat digunakan sebagai suplemen makanan, suplemen untuk pasien penderita hiperkolesterolemia dan diabetes mellitus, dan sebagai sumber antioksidan alami bagi tubuh (5).

Berdasarkan hasil penelitian pada tahun 2016, dekokta akar durian memiliki aktivitas penghambatan enzim $\alpha$-glukosidase dengan IC50 2,66 ppm terhadap DPPH (6) dan juga pada tahun 2017 ekstrak etanol akar durian memiliki nilai IC50 3,38 bpj dalam menghambat enzim alfa glukosidase (7). Penghambatan kerja enzim ini dapat memperlambat absorbsi glukosa dalam usus halus, sehingga memberikan efek menurunkan kadar glukosa darah sesudah makan (8). Jika terdapat kandungan senyawa dalam suatu bagian tanaman maka di bagian lain tanaman tersebut juga diperkirakan memiliki kandungan yang sama.

Golongan obat penghambat $\alpha$-glukosidase yang digunakan saat ini seperti acarbose, miglitol dan voglibose dianggap kurang aman karena dapat menyebabkan gangguan pada saluran pencernaan yaitu kembung dan flatulens (9). Oleh karena itu pengobatan dengan tanaman obat dapat digunakan sebagai alternatif dalam pengembangan obat yang lebih potensial dan efektif serta biaya yang lebih terjangkau dibandingkan dengan obat antidiabetik oral. 


\section{METODE PENELITIAN}

\section{Pengambilan dan pengumpulan sampel}

Akar, klika dan daun durian (Durio zibethinus Murr.) yang diperoleh kota Palopo, Sulawesi Selatan dan dideterminasi di Laboratorium Biologi, Matematika dan Ilmu Pengetahuan Alam, Universitas Negeri Makassar. Sampel dicuci dengan air mengalir untuk menghilangkan kotoran yang menempel dan kemudian dikeringkan dalam oven simplisia dengan suhu 400C sampai menjadi simplisia. Sampel yang telah kering disortasi kemudian diserbukkan (mesh 20) dan disimpan diwadah tertutup rapat untuk digunakan dalam prosedur selanjutnya.

\section{Penyiapan Sampel \\ Pembuatan ekstrak etanol durian}

Ekstraksi dilakukan dengan menggunakan metode maserasi menggunakan pelarut etanol $70 \%$. Serbuk akar, klika dan daun durian ditimbang sebanyak 500 g kemudian dimasukkan ke dalam wadah maserasi dan dibasahi terlebih dahulu dengan pelarut etanol hingga serbuk simplisia terendam. Setelah itu pelarut yang tersisa ditambahkan dengan rasio 1:10 atau sampai volume pelarut mencapai $5 \mathrm{~L}$. Direndam selama 6 jam pertama sambil diaduk sesekali, lalu diamkan selama 18 jam. Pesahkan hasil maserasi dengan cara difiltrasi. Ulangi proses ini setidaknya dua kali dengan jenis dan jumlah pelarut yang sama. Semua maserat dikumpulkan, lalu diuapkan dengan evaporator sampai diperoleh ekstrak. Setelah itu, dimasukkan ke dalam eksikator.

\section{Pembuatan suspensi NaCMC 1\%}

Suspensi NaCMC 1\% dibuat dengan melarutkan NaCMC sebanyak $1 \mathrm{~g}$ ke dalam aqua destilata yang telah dipanaskan pada suhu $70{ }^{\circ} \mathrm{C}$, lalu dicukupkan hingga $100 \mathrm{~mL}$. Kemudian diaduk hingga terdispersi sempurna menggunakan pengaduk elektrik.

\section{Pembuatan larutan glukosa 20\%}

Glukosa yang digunakan adalah $2 \mathrm{~g} / \mathrm{kgBB}$ (10), maka dosis yang digunakan untuk mencit $20 \mathrm{~g}$ adalah $40 \mathrm{mg}$. D-glukosa ditimbang sebanyak $5 \mathrm{~g}$ kemudian dilarutkan dengan aqua destilata, dan dicukupkan volumenya hingga $25 \mathrm{~mL}$.

\section{Pembuatan suspensi acarbose}

Dosis pada manusia dewasa adalah $50 \mathrm{mg}$ (11) maka dosis untuk mencit $20 \mathrm{~g}$ adalah 0,0166 mg. Maka terlebih dahulu ditimbang satu per satu tablet acarbose sebanyak 30 tablet, kemudian dihitung bobot rata-rata. Hasil yang diperoleh dimasukkan kedalam rumus perhitungan sebagai berikut:

Berat tablet yang ditimbang $=$ (Bobot yang diinginkan)/(Bobot etiket) $\mathrm{x}$ bobot rata-rata. Digerus halus 30 tablet acarbose, lalu ditimbang 5,23 mg dan dimasukkan kedalam lumpang ditambahkan suspensi NaCMC 1\% sedikit demi sedikt sambil di gerus hingga homogen lalu dimasukkan kedalam labu tentukur $25 \mathrm{~mL}$ dan volume dicukupkan dengan suspensi NaCMC 1\% hingga tanda.

\section{Pembuatan larutan aloksan}

Dosis aloksan pada tikus adalah $125 \mathrm{mg} / \mathrm{kgBB}$ (12), maka dosis untuk mencit $20 \mathrm{~g}$ adalah 3,5 mg. Aloksan monohidrat ditimbang sebanyak $437,5 \mathrm{mg}$ kemudian dilarutkan dengan $\mathrm{NaCl}$ fisiologis, dan dicukupkan volumenya hingga $25 \mathrm{~mL}$ dalam labu tentukur.

\section{Pembuatan suspensi ekstrak durian}

Dosis ekstrak yang akan diberikan adalah $125 \mathrm{mg} / \mathrm{kgBB}, 250$ $\mathrm{mg} / \mathrm{kgBB}$ dan $500 \mathrm{mg} / \mathrm{kgBB}$, maka dosis untuk $20 \mathrm{~g}$ mencit adalah 2,5 mg, $5 \mathrm{mg}$ dan $10 \mathrm{mg}$. Ekstrak akar, klika dan daun durian ditimbang sebanyak $125 \mathrm{mg}, 250 \mathrm{mg}$ dan $500 \mathrm{mg}$ lalu didispersikan dengan NaCMC 1\% hingga homogen lalu dicukupkan volumenya hingga $10 \mathrm{~mL}$ dalam labu tentukur (konsentrasi 1,25\%, 2,5\% dan 5\%).

\section{Uji aktivitas antihipoglikemia}

Hewan uji yang digunakan yaitu mencit jantan dengan bobot badan 20-40 g yang dibagi menjadi 6 kelompok secara acak. Semua kelompok kecuali kelompok kontrol sehat diinjeksikan larutan aloksan monohidrat secara subkutan dengan dosis $125 \mathrm{mg} / \mathrm{kgBB}$, dan kelompok kontrol sehat diberi suspensi NaCMC 1\%. Hasil induksi selama 3 hari, dipilih mencit yang masuk kriteria inklusi yaitu glukosa darah $>200 \mathrm{mg} / \mathrm{dL}$ lalu diberi perlakuan sesuai kelompok. Namun terlebih dahulu mencit dipuasakan selam 6- 8 jam sebelum perlakuan.

Kelompok 1 (kontrol sehat) yaitu kelompok mencit yang tidak diberikan perlakuan. Kelompok 2 (kontrol negatif) yaitu kelompok mencit diberi suspensi NaCMC $1 \%$. Kelompok 3 (kontrol positif) yaitu kelompok mencit yang diberi suspensi acarbose. Kelompok 4 yaitu kelompok mencit yang diberi ekstrak etanol akar durian (EDR), ekstrak klika (ESB), dan ekstrak daun durian (EDL) dosis $125 \mathrm{mg} / \mathrm{kg}$ BB. Kelompok 5 yaitu kelompok mencit yang diberi ekstrak etanol akar durian (EDR), ekstrak klika (ESB), dan ekstrak daun durian (EDL) dosis $250 \mathrm{mg} / \mathrm{kg}$ BB. Kelompok 6 yaitu kelompok mencit yang diberi ekstrak etanol akar durian (EDR), ekstrak klika (ESB), dan ekstrak daun durian (EDL) dosis $500 \mathrm{mg} / \mathrm{kg} \mathrm{BB}$.

Masing-masing kelompok kemudian diberikan larutan glukosa $2 \mathrm{~g} / \mathrm{kgBB} 30$ menit setelah perlakuan. Perlakuan diberikan secara peroral. Sampel darah kemudian diambil dari vena pada ekor mencit. Pengukuran glukosa darah dilakukan sebelum induksi aloksan (t-0), 3x24 jam setelah induksi (t-3), dan 30 menit setelah pemberian larutan glukosa selama 180 menit (t30, t60, t90, t120, t150 dan t180), dilakukan pengukuran glukosa darah dengan menggunakan alat glucometer (Nesco $囚)$

\section{Persentase penurunan kadar glukosa darah}

Untuk membandingkan efek penurunan kadar glukosa darah antar kelompok, maka dilakukan perhitungan selisih kadar setelah pemberian aloksan (t0) dengan kadar pada waktu pengukuran tertentu, serta persentase penurunan kadar glukosa darah dengan rumus sebagai berikut (13)

\section{$\%$ Penurunan $=$}

$\frac{\text { kadar glukosa t0 }- \text { kadar glukosa waktu pengukuran }}{\text { kadar glukosa t0 }} \times 100 \%$

\section{Analisis data}

Data dianalisis menggunakan SPSS 20 menggunakan metode one way ANOVA. Hasil dinyatakan signifikan apabila Pvalue $<0,05$.

\section{HASIL DAN PEMBAHASAN}

Penelitian ini bertujuan untuk menentukan aktivitas ekstrak etanol akar, klika, dan daun durian dalam menurunkan kadar glukosa darah pada mencit yang diinduksi aloksan. 
Simplisia yang telah diperoleh, dilanjutkan ke tahap ekstraksi menggunakan metode maserasi. Penggunaan pelarut etanol sebagai penyari adalah karena etanol dikenal sebagai pelarut yang baik untuk ekstraksi dan aman untuk dikonsumsi manusia, netral dan memiliki daya serap yang baik (14). Selain itu etanol $70 \%$ yang merupakan pelarut polar digunakan untuk maserasi sehingga zat aktif dalam sampel, terutama polifenol, juga bisa tertarik oleh pelarut. Hasilnya dapat dilihat pada Tabel 1.

\begin{tabular}{ll} 
Tabel 1. Hasil Ekstraksi & \\
\hline Parameter & Hasil \\
\hline Metode Ekstraksi & Maserasi \\
Bobot ekstrak akar & 36,52 gram \\
Bobot ekstrak klika & 24,32 gram \\
Bobot ekstrak daun & 25,18 gram \\
Persentase rendemen ekstrak akar (\% ) & $8,26 \%$ \\
Persentase rendemen ekstrak klika (\%) & $5,49 \%$ \\
Persentase rendemen ekstrak daun(\%) & $5,03 \%$ \\
\hline
\end{tabular}

Setelah didapatkan ekstrak kemudian dilakukan pengujian aktivitas antihiperglikemia ekstrak etanol akar, klika dan daun durian terhadap mencit yang telah diinduksi aloksan dan telah memenuhi kriteria inklusi pengujian yaitu kadar glukosa darah $>200 \mathrm{mg} / \mathrm{dL}$ (15).

Pengukuran kadar glukosa darah normal dilakukan terlebih dahulu sebelum induksi aloksan, untuk mengetahui perbedaan kadar glukosa normal dan setelah induksi aloksan. Berdasarkan perbandingan kadar glukosa tersebut dapat diketahui bahwa hewan uji mengalami peningkatan kadar glukosa darah setelah induksi aloksan. Pengukuran kadar glukosa darah pada mencit dilakukan selama 3 jam dengan interval waktu 30 menit. Hal ini berdasarkan literatur yang menyatakan bahwa absorbsi glukosa dalam tubuh memerlukan waktu sekitar 30-60 menit dan akan menurun setelah 2-3 jam, maka untuk melihat penurunan kadar glukosa yang lebih jelas digunakan jangka waktu selama 3 jam setelah pemberian ekstrak. Pengukuran kadar glukosa darah mencit dilakukan dengan menggunakan alat glukometer.

Kemampuan sampel uji untuk menurunkan kadar glukosa darah dapat dihitung dengan membandingkan kadar glukosa darah tiap pengukuran terhadap glukosa awal. Rata-rata persen penurunan kadar glukosa darah selama 180 menit untuk setiap kelompok perlakuan dapat dilihat pada Gambar 1,2 , dan 3 .

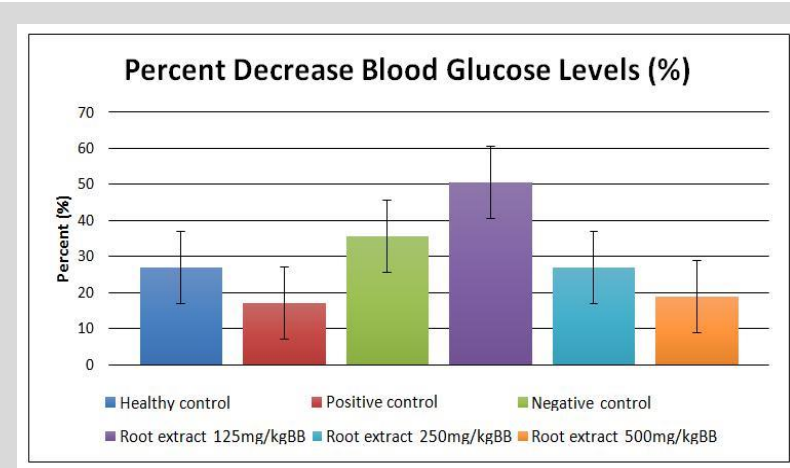

Gambar 1. Penurunan kadar glukosa darah ekstrak akar durian pada menit ke-180

Dari diagram batang penurunan kadar glukosa darah pada menit ke-180 (Gambar 1) menunjukkan persen penurunan kadar glukosa darah yang paling besar yaitu pada ekstrak etanol akar durian pada dosis $125 \mathrm{mg} / \mathrm{kgBB}$ dengan nilai persen penurunan sebesar $50.60 \%$ dibandingkan dengan kelompok perlakuan lainnya. Dimana nilai persen penurunan untuk ekstrak etanol akar durian dosis $250 \mathrm{mg} / \mathrm{dL}$ dan 500 $\mathrm{mg} / \mathrm{dL}$ berturut-turut sebesar 26,97\% dan 19,02\%. Sedangkan kontrol positif menunjukkan nilai persen penurunan sebesar $17,02 \%$. Hal ini menunjukkan nilai persen penurunan kadar glukosa darah pada berbagai variasi konsentrasi ekstrak lebih besar dibandingkan dengan persen penurunan dari kontrol positif yang dalam hal ini adalah obat acarbose.

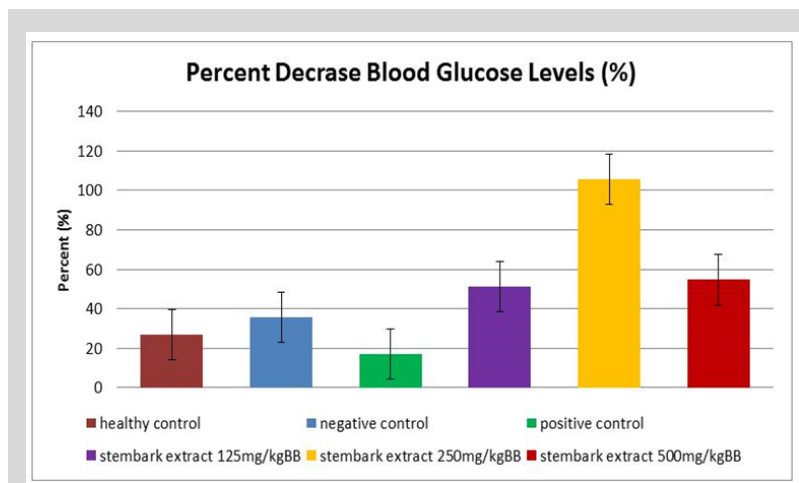

Gambar 2. Penurunan kadar glukosa darah ekstrak klika durian pada menit ke-180

Sama seperti gambar 1, penurunan kadar glukosa darah pada menit ke-180 (Gambar 2) menunjukkan persen penurunan kadar glukosa darah yang paling besar yaitu pada ekstrak etanol klika durian pada dosis $250 \mathrm{mg} / \mathrm{kgBB}$ dengan nilai persen penurunan sebesar 105,62\% dibandingkan dengan kelompok perlakuan lainnya. Dimana nilai persen penurunan untuk ekstrak etanol akar durian dosis $125 \mathrm{mg} / \mathrm{dL}$ dan 500 $\mathrm{mg} / \mathrm{dL}$ berturut-turut sebesar $51,16 \%$ dan 54,61\%. Sedangkan kontrol positif menunjukkan nilai persen penurunan sebesar $17,02 \%$. Hal ini menunjukkan nilai persen penurunan kadar glukosa darah pada berbagai variasi konsentrasi ekstrak lebih besar dibandingkan dengan persen penurunan dari kontrol positif yang dalam hal ini adalah obat acarbose.

Penurunan kadar glukosa darah pada menit ke-180 (Gambar 3) menunjukkan persen penurunan kadar glukosa darah yang paling besar yaitu pada ekstrak etanol daun durian pada dosis $500 \mathrm{mg} / \mathrm{kgBB}$ dengan nilai persen penurunan sebesar $62,97 \%$ dibandingkan dengan kelompok perlakuan lainnya. Dimana nilai persen penurunan untuk ekstrak etanol daun durian dosis $125 \mathrm{mg} / \mathrm{dL}$ dan $250 \mathrm{mg} / \mathrm{dL}$ berturut-turut sebesar $25,22 \%$ dan $32,29 \%$. Sedangkan kontrol positif menunjukkan nilai persen penurunan sebesar $17,02 \%$. Hal ini menunjukkan nilai persen penurunan kadar glukosa darah pada berbagai variasi konsentrasi ekstrak lebih besar dibandingkan dengan persen penurunan dari kontrol positif yang dalam hal ini adalah obat acarbose.

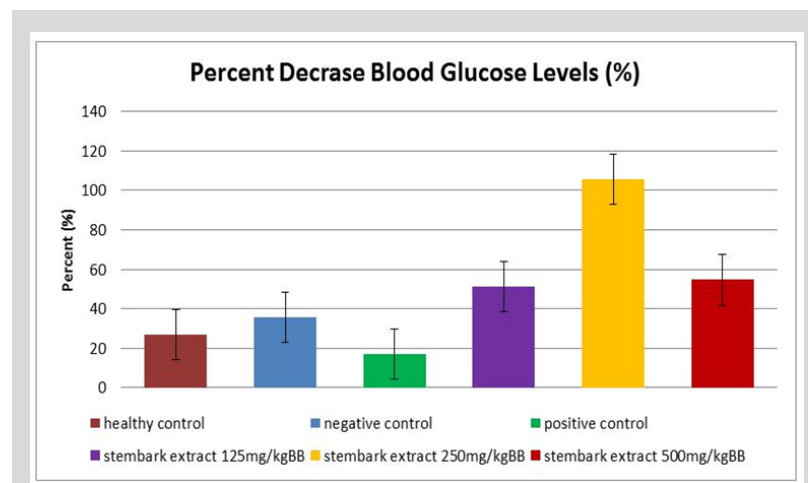

Gambar 3. Penurunan kadar glukosa darah ekstrak daun durian pada menit ke-180 
Penurunan kadar glukosa darah dalam ekstrak akar durian disebabkan oleh adanya senyawa yang dapat menghambat aktivitas enzim $\alpha$-glukosidase, yaitu polifenol. Senyawa polifenol memiliki kemampuan untuk berikatan dengan protein sehingga dapat menghambat enzim pengurai karbohidrat seperti enzim $\alpha$-glukosidase (16). Sesuai dengan penelitian sebelumnya, ekstrak etanol akar durian mrmiliki nilai IC 3,38 bpj dalam menghambat enzim $\alpha$-glukosidase (7). Sementara klika da daun durian juga dicurigai memiliki senyawa yang sama dengan akar durian yang dapat menurunkan kadar glukosa darah.

Kemampuan ekstrak etanol durian dalam menurunkan kadar glukosa darah diduga karena kandungan flavonoid. Diduga mekanisme kerja flavonoid yang meregenerasi dan merangsang pelepasan insulin oleh sel $\beta$ pankreas. Selain itu ada tiga mekanisme penurunan kadar glukosa darah sebagai tanaman antidiabetik yang potensial, antara lain: 1) memiliki kemampuan sebagai adstringen untuk dapat mengendapkan protein membran mukosa usus dan membentuk lapisan yang melindungi usus, sehingga dapat menghambat asupan glukosa, 2) mempercepat pelepasan glukosa dari sirkulasi dengan mempercepat filtrasi dan ekskresi ginjal, 3) mempercepat pelepasan glukosa melalui peningkatan metabolisme atau memasukkan ke dalam deposit lemak, suatu proses yang melibatkan pankreas untuk memproduksi insulin (17).

Durian dilaporkan mengandung flavonoid, yaitu catechin dan quercetin serta polifenol dan tanin. Quercetin memiliki aktivitas Aldos reductase inhibitor yang berpotensi dapat digunakan dalam terapi antihiperglikemia (17).

Dari hasil penelitian ini ditemukan bahwa ekstrak etanol akar durian, kilka, dan daun durian memiliki potensi untuk digunakan sebagai bagian dari terapi untuk diabetes mellitus atau sebagai antihiperglikemik.

\section{KESIMPULAN}

Berdasarkan hasil penelitian yang telah dilakukan, dapat diambil sebuah kesimpulan awal bahwa ekstrak etanol dari akar, klika dan daun durian memiliki potensi untuk menurunkan kadar glukosa darah pada mencit yang diinduksi aloksan.

\section{DAFTAR PUSTAKA}

1. Greenspan, FS dan Baxter, JD.. Endokrinologi Dasar dan Klinik. Ed. 4. Penerbit Buku Kedokteran EGC. Jakarta. 574-779, 2000.

2. American Diabetes Association (ADS)., Standars of Medical Cer in Diabetes., Diabetes Care., 2017, Vol.40, Sup.1

3. Cahyono, A. Manfaat Susu Kedelai sebagai Terapi Penurun Kadar Glukosa Darah pada Klien Diabetes Mellitus (Study Ekspeimental di Poli Penyakit dalam RSUD Pare Kabupaten Kediri Tahun 2010). 2011. Jurnal Akademi Keperawatan Pamenang. 2. (4): 28-37.

4. Leonyta, E. dan Muliani, A. Penggunaan Obat Tradisional oleh Penderita Diabetes melitus dan Faktor-faktor yang Berhubungan di Wilayah Kerja Puskesmas Rajosari Pekanbaru Tahun 2015. Jurnal Kesehatan Komunitas. 2015.3. (1): 47-52

5. Widyawati, A.T. dan Nurbani. Mini Review: Teknologi inovasi budidaya durian di Kalimantan Timur. Pros Sem Nas Masy Biodiv Indon. 2017. 3. (1): $132-137$.

6. Wahyudin, E., Agustina, R., Evary, Y.M., dan Rahim, A. 2016. Tinjauan Farmakologi In Vitro dan In Vivo: Tanaman Obat dan Ramuan Antidiabetes Berbasis Kearifan Lokal Etnis Sulawesi Selatan. Makassar.

7. M. Yayu, M.N. Amir, Antioxidant and Antidiabetes Capacity of Hexane, Ethylacetate and Ethanol Extracts of Durio zibethinus Murr. Root, Pharmacognosi Journal, 2017. Volume 10 (5)

8. Departemen Kesehatan RI. Pharmaceutical Care untuk Penyakit Diabetes melitus. Direktorat Bina Farmasi Komunitas dan Klinik. 2005. Jakarta.

9. Supardi, S. dan Susyanty, A.L. Penggunaan Obat Tradisional Dalam Upaya Pengobatan Sendiri Di Indonesia (Analisis Data Susenas Tahun 2007). Bul. Penelit. Kesehat. 2010. 38. (2): 80-89.

10. Ramadani, F.H., Intannia, D., dan Ni'mah M. Profil Penurunan Kadar Glukosa Darah Ekstrak Air Rambut Jagung (Zea Mays L.) Tua dan Muda Pada Mencit Jantan Galur Balb-C. Jurnal Pharmascience, 2016., Vol 3 (1): $37-44$.

11. Darmawi, A.R., Saleh, C., dan Kartika R. Aktivitas Antihiperglikemik dari Ekstrak Etanol dan N-Heksana Daun Kembang Bulan (Tithonia diversifolia A.Gray) pada Tikus Putih Jantan. Jurnal Kimia Mulawarman. 2015. Vol 12: 60-63

12. Mathalaimutoo, A., Wilar, G., dan Wardoyo, M.M. Aktivitas Antidiabetes Ekstrak Etanol Daun Mangga Bapang (Mangifera Indica L. Var. Bapang) pada Tikus Galur Wistar yang Diinduksi Aloksan. Jurnal Matematika dan Sains. 2014. 20(2);15-17

13. Fitrianingsih,S.P., Lestari,F., dan Aminah,S. Aktivitas Antihiperglikemia Ekstrak Etanol Kulit Buah Salak (Salacca zalacca (Gaertner) Voss) Terhadap Mencit Diabetes yang Diinduksi Aloksan. Jurnal Matematika dan Sains. 2015.20(1);12-17

14. Direktorat Jenderal Pengawasan Obat dan Makanan. Parameter Standar Umum Ekstrak Tumbuhan Obat. Departemen Kesehatan Republik Indonesia. 1986.

15. Muhtadi, Primarianti, A.U. dan Sujono, T.A. Antidiabetic Activity of Durian (Durio zibethinus Murr.) and Rambutan (Nephelium lappaceum L.) Fruit Peels in Alloxan Diabetic Rats. Procedia Food Science, Elsevier. 2015. (3): 255-261.

16. Griffiths, D.W., dan Moseley, G. The Effect of Diets Containing Field Beans of High or Low Polyphenolic Content of the Activity of Digestive Enzymes in the Intestines of Rats. J. Sci Food Agric. 1980.31:255-259.

17. Muhtadi, M., Haryoto, H., Sujono, T.A., dan Suhendi, A. Antidiabetic and Antihypercholesterolemia Activities of Rambutan (Nephelium Lappaceum L.) and Durian (Durio zibethinus Murr.) Fruit Peel Extracts. Journal of Applied Pharmaceutical Science. 2016. 6. (4): 190-194. 